\title{
Pääkirjoitus
}

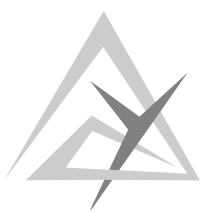

Nina V. Nygren ${ }^{a}$ ja Jussi Semi ${ }^{b}$

\section{Julkaistaan suomeksi?}

Kaksikymmentä vuotta sitten Jari Eskola ja Juha Suoranta (1998, 248-250) nostivat esiin kysymyksen kansainvälisen julkaisemisen roolista suomalaisessa tiedeyhteisössä. Keskustelua leimasi tuolloin (ja myös sen jälkeen) dikotominen asetelma, jossa vieraskielinen julkaisutoiminta nähdään joko tieteellisen ilmaisun tuhona tai edellytyksenä tieteen tuloksellisuudelle. Eskola ja Suoranta esittivät kysymyksen, jota on syytä pohtia myös nyt, kun kansainvälisestä (lue: englanninkielisestä) julkaisemisesta on muodostunut kyseenalaistamaton itsestäänselvyys: "nostaako vieraalla kielellä kirjoittaminen jotenkin tieteen tasoa?"

Miksi sitten kannattaisi julkaista suomeksi? Ensinnäkin vaarana on suomenkielisen tieteellisen termistön kuihtuminen. Tämä ei tarkoita yksinomaan kielen rappeutumista vaan myös käsitteiden supistumista tai jopa katoamista. Kun kunnollisia kotimaisia vastineita ei ole olemassa, tuloksena on puheen ja kirjoitetun kielen puuroutuminen englannin ja suomen sekamelskaksi. Viestintä saa helposti koomisia sävyjä, kun englanninkielistä termistöä ujutetaan paikkoihin, joihin suhteellisen vähällä vaivalla olisi ollut mahdollista löytää kotimainen vastine. Kyse ei ole yksinomaan älyllisestä laiskuudesta vaan myös siitä, että vieraskielisyydestä ja sen käytöstä on muodostunut normaali viestinnän tapa.

Toiseksi on kysyttävä, kuka lukee tieteellisiä julkaisuja vai lukeeko niitä kukaan. Jos alan tutkijat haluavat saada laajemman kaikupohjan tutkimustensa keskeisimpään sanomaan, kansainväliset tieteelliset lehdet eivät ole tähän paras ratkaisu. Syy on yksinkertainen: niitä eivät lue päättäjät eivätkä ne välttämättä herätä mielenkiintoa muualla yhteiskunnassa. Suomenkielinen julkaiseminen mahdollistaa kosketuksen paikalliseen ja kansalliseen ei-akateemiseen lukijakuntaan. On järjetöntä resurssien haaskausta rahoittaa suomalaista yhteiskuntaa ja sen kehittämistä käsittelevää tutkimusta, mikäli keskeisimmät tutkimustulokset löytyvät yksinomaan kansainvälisistä julkaisusarjoista ja maksumuurien takaa.

Kolmanneksi vaatimus englanniksi kirjoittamisesta voi osoittautua liian haastavaksi monelle uransa alkutaipaleella olevalle tutkijalle. Tilanne on yksittäiselle tutkijalle hankala ja liian usein kestämätön. Vaatimukset kansainvälisiin vertaisarvioituihin lehtiin kirjoittamisesta saattavat osoittautua liian vaativiksi, aikaa vieviksi ja viime kädessä tarpeettomiksi. Pahimmillaan seurauksena on tutkijauran päättyminen ennen kuin se on edes kunnolla alkanut.

Kokonaisuudessaan tilanne on ongelmallinen. Yhtäältä voidaan syyttää suomalaista tiedepolitiikkaa, mutta toisaalta myös tutkijoiden on katsottava peiliin. Alistuvatko rohkeina ja kriittisinä tieteellisinä toimijoina itseään pitävät tutkijat nöyrästi tiedepolitiikan pelinappuloiksi? Kahvipöydissä ja käytävillä osaamme kritisoida julkaisupolitiikan osittaista mielettömyyttä, mutta käytännössä alistumme toimimaan siinä muodossa, jossa meidän odotetaan toimivan.

Käsillä oleva lehden numero on täynnä tärkeää, suomenkielistä, avointa ja erilaisiin yhteiskunnallisiin keskusteluihin osallistuvaa tieteellistä tekstiä. Kriittiset ja uudet avaukset eivät jää yksinomaan tämän lehden kansien väliin. Toukokuussa 2018 julkaistiin uusiutunut Versus-verkkojulkaisu (https://

a. Tampereen yliopisto, nina.nygren@uta.fi, b. Itä-Suomen yliopisto, jussi.semi@uef.fi; 
www.versuslehti.fi/), joka on kolmen tieteellisen seuran (Alue- ja ympäristötutkimuksen seura, Yhteiskuntatieteellisen ympäristötutkimuksen seura ja Suomen maantieteellinen seura) yhdessä kustantama verkkojulkaisu. Versuksen tehtävänä on edistää alojensa tutkimuksen saavutettavuutta, näkyvyyttä ja vaikuttavuutta.

Lehti on siirtynyt tämän numeron myötä tekijänoikeuksien suhteen CC BY 4.0 -lisenssiin, joka on laajalti käytössä avoimessa julkaisutoiminnassa. Lyhyesti sanottuna: CC BY 4.0 lisenssi tarkoittaa sitä, että kuka tahansa saa ilman korvausta kopioida teosta ja levittää sitä edelleen missä tahansa välineessä ja muodossa muutettuna tai muuttamattomana, kuitenkin edellyttäen että teoksen julkaisemisen yhteydessä ilmoitetaan tekijän tai tekijöiden nimi ja noudatetaan muita lisenssin ehtoja.

Lehden käyttämää journal.fi -alustaa kehitetään jatkuvasti, mikä helpottaa toimituksen, mutta myös kirjoittajien ja vertaisarvioijien työtä - jatkakaa siis kirjoittamista ja vastatkaa myönteisesti arviointipyyntöihin! Lisäksi lehden graafista ilmettä kehitetään Tiedekustantajien liitolta saadun apurahan turvin - olkaa kuulolla tänä syksynä!

Seuraavan numeron 2/2018 teemana on ympäristöpoliittinen ruoka, johon vielä ehdit tarjota esimerkiksi aiheeseen liittyvää kirja-arviota (max. 1000 sanaa). Vertaisarvioimattomien kirjoitusten deadline on 15.9.2018. Ensi vuoden 1/2019 numeroon tarjottavien artikkeli- ja katsauskäsikirjoitusten deadline on 15.1.2019 ja vertaisarvioimattomien 30.3.2019.

Rentouttavaa kesää lehden lukijoille!

\section{Lähteet}

Eskola, J. \& Suoranta, J. (1998) Johdatus laadulliseen tutkimukseen. Vastapaino, Tampere. 